\title{
A környezetpolitika múltja, jelene, jövője - gondolatok egy könyv alapján
}

Az alábbiakban Jan Laitos Why Environmental Policies Fail c. könyvét mutatom be, kiegészítve a könyv által inspirált észrevételeimmel. ${ }^{1}$ A mü 2017-ben jelent meg a Cambridge Kiadó gondozásában. A szerző a Denveri Egyetem Jogi Karán tanít (University of Denver Sturm College of Law) az Amerikai Egyesült Államokban. Számos környezetjogi vonatkozású könyvet, tanulmányt publikált már.

Ha lényegre törően akarom megfogalmazni, akkor azt mondhatom, hogy a könyv annak az okait kutatja, hogy az amúgy jó szándékú környezetpolitikai törekvések miért sikertelenek az ember által okozott környezetpusztítás megakadályozásában. Ugyanakkor a szerző továbbmegy a címben is jelzett „miért"-ek keresésén, és új szemléletet, új környezetpolitikát javasol, amelynek a létjogosultságát és sikerességét az adja, hogy olyan egyetemes igazságokra épít, mint amelyekre Földünk ökoszisztémája, illetve az univerzum magasabb erői is. Mielőtt azonban belevágna a közepébe, a szerző a könyv előszavában röviden bemutatja azt a két rendszert, amelynek ütközése életre hívta a környezetpolitikát, vagyis azoknak az intézkedéseknek az összességét, amelyek a természeti környezet védelmére törekednek. Ez a két rendszer a gazdasági és természeti rendszer. A gazdasági rendszer az antropocentrikus növekedést állítja előtérbe, amelyet szinte valamennyi földi társadalom elfogad. A gazdasági növekedésbe, az anyagi javak gyarapításába vetett kollektív hit oda vezetett, hogy az embert körbeölelő természeti környezet - fák, ásványok, föld, víz, levegő - csupán az emberközpontú célok (mint népességnövekedés, városiasodás, nagyobb GDP, egyéni jólét növelése, versenyző piacok) megvalósításának eszközévé vált. Ezt az emberközpontú szemléletet ráadásul néhány, hosszú ideig szinte megdönthetetlen feltételezés is támogatta (például jobban értékeljük a jelent a jövőnél, a rövid távú érdekeket a hosszú távú érdekeknél; a kifogyhatatlan erőforrások mítosza; a természet az emberért van). Ennek eredményeképpen a természeti környezetet (természeti rendszert) túlhasználták, megmérgezték, tönkretették. Ennek számos tünete van a klímaváltozástól kezdve, az ökoszisztéma-

* Dr. Bányai Orsolya egyetemi adjunktus, DE ÁJK Agrárjogi, Környezetjogi és Munkajogi Tanszék, Debrecen. banyai.orsolya@law.unideb.hu.

LAITOS, Jan-OKULSKI, Juliana: Why environmental policies fail. Cambridge University Press, Cambridge, 2017, 215p.

2 Környezetpolitika alatt a szerző döntéseket vezérlö kormányzási filozófiát ért, amelyet gyakran környezeti kérdéseket érintő jogszabályokba is átültetnek. Az ilyen politika (policy) létrejöhet egy végrehajtandó döntéssel (például az Amerikai Egyesült Államok elnökének utasításával), amely ezt követően egy jogalkotási aktus eredményeképpen közigazgatási úton végrehajtható pozitív joggá alakul. A környezetpolitika tehát a környezetet érintő emberi magatartások szabályozása mögött húzódó, gyakran jogszabályokat indukáló filozófia. 
szolgáltatások romlásán, a Föld nitrogén- és foszforkörforgásának megzavarásán, az erdők kiterjedésének csökkenésén, drámai mértékü fajkihaláson (biodiverzitáscsökkenésen) át, az óceánok savasodásáig. A szerző három tekintélyes elméletet emel ki, amelyeket az ember környezetre gyakorolt hatásának megragadására alakítottak ki. Az első - széles körben támogatott - elmélet szerint egy új földtörténeti korszakba, az ún. antropocén (Anthropocene) korszakba léptünk. Az emberi tényező hatása ugyanis a Föld atmoszférájára olyan jelentős, hogy a földtudományok képviselői szerint ezt már egy új földtörténeti korszaknak kell tekinteni. Második elméletként a „földi korlátokat” (Planetary Boundaries) emeli ki. Eszerint bizonyos kereteken belül az ember biztonságosan élhet a Földön. Ha azonban az emberi tevékenységek egyes természeti rendszerek kapcsán átlépik a biztonsági korlátot, az emberi élet többé nem fenntartható a Földön. A harmadik elv a "nagy gyorsulás” (Great Acceleration) elmélete. Eszerint az antropocén kor kezdete óta meredeken (exponenciálisan) növekszik a természeti erőforrások felhasználása, illetve a környezetszennyezés. Ezt a gyors környezeti változást fémjelzik a "nagy gyorsulás” kifejezéssel. Az elmélet szerint egyre gyorsuló ütemben tartunk abba az irányba, hogy átlépjük a földi természeti korlátokat. A két említett (gazdasági és természeti) rendszer ütközéséből származó problémákat a környezetpolitika volt hivatott kezelni. Csakhogy a szerző szerint egyre többen látják úgy, hogy ebben az ökológiai szükséghelyzetben a már meglévő környezetpolitikai eszközök, radikális változtatás vagy innováció, kreativitás nélkül alkalmatlanok a helyzet kezelésére. Több példát említ ezen új, innovatív környezetpolitikai eszközökre (a természet jogainak jogi elismerése, az emberi magatartás mozgatórugóinak figyelembevétele, a környezethez való jog újragondolása stb.), de fontosnak tartja kiemelni, hogy még mielőtt bármit is javasolna, meg kell érteni, hogy a hagyományos környezetpolitika miért van kudarcra ítélve. A könyv első négy része ezt (a kudarc okait) taglalja, illetve a tradicionális környezetpolitika történetével és értékelésével foglalkozik. Az ötödik részben pedig a szerző arra tesz javaslatot, hogy - tanulva az eddigi hibákból - milyennek kellene lennie az új környezetpolitikának. Az alábbiakban a könyv felépítését követve ismertetem Laitos gondolatmenetét. A könnyebb nyomon követhetőség érdekében csak ezt követően fogalmazom meg saját észrevételeimet a könyvvel kapcsolatban, egy erre szánt külön pontban.

\section{1. „A kertész és a beteg kert”}

Az első rész „A kertész és a beteg kert” (The gardener and the sick garden) címet viseli. Ebben a szerző először is azt taglalja, hogy a hagyományos környezetpolitika alapvetően téves feltevésekre alapoz a következőkkel kapcsolatban: 1. hogyan müködik a természet; 2. hogyan tulajdonítanak az emberek értéket a természeti erőforrásoknak (natural resources); 3. hogyan cselekednek az emberek. Feltételezések helyett, illetve ahelyett, hogy mi emberek mit szeretnénk, hogyan müködjön a természet, a környezetpolitikának tudományos tényekre kellene alapoznia, és a megfelelő kialakításukhoz a következő kérdésekre kellene helyes választ adni: 1. Hogyan müködik valójában a természet? 2. Valójában az embereknek miként kelle- 
ne értékelnie a természeti eröforrásokat? 3. Hogyan hoznak döntéseket és miként választanak az emberek? A következőkben a fenti kérdéseket és az azokra adott válaszokat fejtem ki egy kicsit részletesebben.

Azzal kapcsolatban, hogy hogyan müködik a természet, Laitos szerint egyfelöl az a téves felfogásunk, hogy az ember és a környezet egymástól elkülönült, holott a valóság, hogy mi emberek is szerves részei vagyunk a természeti ökoszisztémának (ezt úgy nevezik, hogy környezeti-társadalmi rendszer; socio-ecological system), azzal pedig együtt fejlődünk (co-evolution). Másfelöl azt is tévesen feltételezzük, hogy a környezetnek van egy olyan természetes, természetközeli állapota, amit a környezetpolitikának meg kellene őriznie vagy vissza kellene állítania. Azonban a tudományos igazság az, hogy nem létezik ilyen ideális természetközeli egyensúlyi állapot, mivel a természeti ökoszisztéma nem statikus, hanem dinamikus, állandó változás jellemzi. A hagyományos környezetpolitika, antropocentrikus jelleggel, az emberi magatartás következményei között, általában csak az emberre gyakorolt hatásokat tartja szem előtt. Elfelejti vizsgálni az emberi magatartás természeti-társadalmi ökoszisztémára gyakorolt hatásait, holott ez a természeti-társadalmi környezet függ az ökoszisztéma szolgáltatásaitól. Pontosan ezért a környezetvédelmi szabályozásnak (környezetpolitikának), amellett, hogy vizsgálja az emberi magatartások környezetitársadalmi rendszerre gyakorolt hatásait, meg kellene öriznie a környezeti-társadalmi rendszer alkalmazkodóképességét (adaptive capacity) is. Végezetül azzal kapcsolatban, hogy miként "müködnek” az emberek, eddig tévesen azt feltételezték, hogy az ember racionális lény. Holott napjaink pszichológiai, neurobiológiai kutatási eredményei ennek éppen ellenkezőjét igazolják. Vagyis az emberek általában korántsem hoznak racionális döntéseket, ehelyett inkább érzelmi, kényelmi alapon (különösen, ha azt a társadalom tagjai széles körben alkalmazzák), a rövid távú érdekeik figyelembevételével, vagy éppen altruizmus, illetve társadalmi nyomás hatására döntenek. Éppen ezért Laitos álláspontja szerint a hagyományos rendészeti (command and control) eszközök kényszere helyett inkább a puha paternalizmus, meggyőzésre épülő szabályozási módszereit kellene alkalmazni. ${ }^{3}$

\section{A környezetpolitika négy korszaka}

A második rész (Part II) a környezetpolitika történetével és értékelésével foglalkozik (A history and assessment of environmental policies). E fejezetben Laitos a környezetpolitika történetének négy korszakát mutatja be. Az első korszak (a 17. század elejétől a 19. század végéig) jellemző mentalitása az ember természethez viszonyított felsőbbrendűségébe vetett hit volt. Ez, kiegészítve a magántulajdonhoz való jog térhódításával, amely a 19. századra az amerikai és európai gazdaság szerves részét jelentette, a hosszú távú hatásokkal mit sem törődve csak fokoz-

3 Ennek lehetőségeit mi is vizsgáltuk, a szóba jövő szabályozási eszköztárnak egy szűkebb körében. BÁnYAl Orsolya-FODOR László: Zöld jelzést kapott? - Termékjelölések a fogyasztó- és a környezetvédelemben. In: Szikora Veronika-Árva Zsuzsanna (szerk.): A fogyasztók védelmének új irányai és kihívásai a XXI. században. Debreceni Egyetem Állam- és Jogtudományi Kar, Debrecen, 2018, 275-294. 
ta a természeti erőforrások egyre intenzívebb felhasználását. A második korszak környezetpolitikája továbbra is az emberi felsőbbrendüséget és a természettől való függetlenséget tükrözi, ugyanakkor e kor szellemiségében már megjelenik a természeti erőforrásoknak a jövő generációk számára történő megőrzésének igénye. Ennek motivációja azonban nem a természet és társadalom egyensúlyának megörzése, hanem az emberi jólét biztosítása. A 20. század közepén kezdődött a harmadik korszak. Ennek sajátossága, hogy a jogalkotók a korábbi felfogással ellentétben rájöttek, hogy igenis vannak ökológiai korlátai a természeti erőforrások felhasználásának. Ugyanakkor az a nézet is jellemezte ezt az időszakot, hogy ha egyes területeket, fajokat „békén hagyunk”, azok képesek maguktól regenerálódni. Ez a szemlélet ugyanakkor nem tükrözi az ökoszisztéma azon sajátosságát, hogy az egy dinamikus és komplex alkalmazkodó rendszer, amelynek nincs egy hoszszan tartó, konstans egyensúlyi állapota. Az utolsó korszak a 20. század második felének végén kezdődött, és napjainkban is tart. Kétségtelenné vált, hogy vannak planetáris, ökológiai korlátok, valamint az is, hogy az embernek igenis van szerepe a földi ökoszisztémában megfigyelhető zavarokban. Mára kezdik felismerni, hogy a környezeti károknak nemcsak az ember, hanem maga a természet is elszenvedője. Ugyanakkor, annak ellenére, hogy egyre többen felismerik a természet és természeti források belső, valódi (intrinsic) értékét, a szabályozás jellemzően még mindig antropocentrikus, az ember természettől való függetlenségén és felsőbbrendüségén alapszik. Az is fémjelzi ezt a kort, hogy a környezeti célok költséghatékony megvalósítására törekednek. Az ökoszisztéma-szolgáltatások jogi védelme emberközpontú gazdasági értékeken nyugszik tehát.

\section{A környezetpolitika megbukott}

A második rész második felében a szerző kimondja, hogy a környezetpolitika és a környezetvédelmi szabályozás megbukott. Ezt azzal igazolja, hogy a nemzetközi tudományos közösség széles körben elismert tagjai között (pl. Will Steffen kémikus; Johan Rockstorm; John Dearing földrajztudós; Anthony Barnosky geológus; Peter Sale ökológus stb.) lényegében konszenzus van abban a tekintetben, hogy az emberi tevékenység olyan mértékben károsította a Föld ökoszisztéma-rendszereit, hogy a bolygó hamarosan már nem tudja biztosítani az emberiség számára a biztonságos létezési feltételeket. Bizonyos korlátok átlépésével a Föld már nem lesz biztonságos az ember számára. E korlátok közül néhányat már átléptünk (pl. klímaváltozás, biodiverzitás csökkenése), más korlátokat (pl. természeti erőforrások - fémek, édesvíz, erdők - kimerülése, légszennyezés, nitrogénkörforgás megváltozása stb.) pedig hamarosan átlépünk. A tudományos bizonyítékok szerint az emberiség egy olyan globális fordulópont (tipping point) előtt áll, amelynek meghaladásával olyan ökológiai változásokkal számolhatunk, amelyekhez már nem tudunk alkalmazkodni. Ez vélhetöen néhány generáción belül bekövetkezik. Mindez azt igazolja, hogy a környezetpolitika bizony nem müködik megfelelöen. Minek tudható be ez a kudarc? Tehetünk-e bármit is annak érdekében, hogy megőrizzük az emberi lét számára megfelelö körülményeket a bolygón? Ezekre a kérdésekre kapjuk meg a következőkben a válaszokat. 
A harmadik részben a szerző részletesen foglalkozik a környezetpolitika bukása mögött álló világnézet egyes problémás elemeivel (Faulty assumptions behind environmental rules). Így az ember és természet dualitásába, illetve az ember más földi élölényekhez képest „kivételes” helyzetébe vetett hittel, ezek pszichológiai mozgatórugóival, valamint a "helyes” világnézet definiálásával. Emellett az első részben már bemutatott (a természet működésével, annak értékelésével és az emberi magatartásokkal kapcsolatos) téves feltételezéseket és azok orvoslását mutatja be aprólékosan.

A negyedik rész kifejezetten a leggyakrabban használt környezetpolitikai eszközöket (rendészeti, gazdasági szabályozó eszközök, közvetlen állami beavatkozás, információszolgáltatás stb.) és azok belső hibáit mutatja be (A critique of existing and proposed strategies). Általános kritikaként fogalmazza meg például a túl sok bürokratikus és top-down megközelítésű jogi elöírás létét, a konzumerizmust, illetve a megkérdőjelezetlen elköteleződést a gazdasági növekedés iránt, vagy azt, hogy a szabályozás sokszor nem számol annak esetleges „mellékhatásaival”. Példaként Kalifornia államot hozza (2016), ahol - miután szembesültek az amúgy ember által előidézett vízhiány okozta rendkívüli szárazsággal - a kormányzó elrendelte a vízfelhasználás korlátozását. Annak hatására azonban, hogy a lakosok nem öntözték a pázsitot, a fák sem jutottak vízhez, ezért fák milliói pusztultak ki. Ezzel a következménnyel pedig nem számoltak elöre.

\section{Univerzális törvényszerűségek}

Az ötödik részben (Part $\mathrm{V}$ ) Laitos részletesen elemzi az általa hivatkozott univerzális törvényeket (Environmental policy must obey the fundamental laws of nature). Mivel azonban e törvények eredőjének - összhangban a természettudományi felfogással - a szimmetria elvét tekinti, mindenekelött ezt mutatja be. A természettudományok (fizika, biológia, matematika, kémia) területén ugyanis úgy vélik, hogy a szimmetria elvéből levezethetők a különféle természeti törvények. A szimmetria modern matematikai megfogalmazásban egyfajta változásmentesség, vagy ahogy a Nobel-díjas Frank Wilczek írja: a szimmetria „változás változás nélkül”. Például az $\mathrm{X}=\mathrm{Y}$ egyenlet szimmetrikus, mert ha $\mathrm{X}$-et $\mathrm{Y}$-ra, míg $\mathrm{Y}$-t $\mathrm{X}$-re cseréljük, akkor $\mathrm{Y}=\mathrm{X}$. A forma ugyan megváltozott, de a tartalom ugyanaz maradt. Ezért mondhatjuk erre, hogy „változás változás nélkül”. A szimmetriát hétköznapi értelemben arra használjuk, amikor valaminek a két oldala szimmetrikus, mint például a pillangó szárnyai esetében. Ezt tükör- vagy kettős szimmetriának nevezik, és csak egy példa a számtalan szimmetria köréből. A szimmetria elvét „a transzformációval szembeni invarianciának"4 is hívják, vagy ahogy Herman Weyl matematikus fogalmazott: „Egy dolog akkor szimmetrikus, ha csinálunk vele valamit, és miután ezt befejeztük, az a dolog ugyanúgy néz ki mint azelőtt." A szimmetria elve érvényesül például az anyagantianyag tekintetében is. Paul Dirac ugyanis már 1928-ban azt feltételezte, hogy

${ }^{4}$ A fordításhoz használt forrás: TöRök Csaba: Szimmetriák és sérülésük. http://atomfizika.elte.hu/magreszfiz/ torokcsaba_paritassertes.pdf (2018. 03. 20.). 
minden szubatomi részecskének (pl. elektron, proton, neutron stb.) van egy ellentétpárja. A negatív töltésü elektronnak például egy pozitív töltésü antielektron párja. Ezt a feltevést később kísérletekkel be is bizonyították. Az antielektront Carl Anderson pozitronnak keresztelte el. A modern fizika tehát mára már tényként kezeli az anyagantianyag létét, és feltételezi annak teljes szimmetriáját. ${ }^{5}$

A szimmetria követelménye további három elvet foglal magában: 1. megőrzés/ megmaradás (conservation), 2. az ekvivalencia (equivalence) és 3. az egység (unification) törvényét. Ezeket itt Laitos részletesebben is kifejti.

A megmaradás törvénye arra a tényre utal, hogy egy kvantitánst nem lehet sem létrehozni, sem elpusztítani. Ha megmérik, ugyanakkora az értéke holnap és holnapután is. Ezt általában a termodinamika első fötételeként, azaz az energiamegmaradás törvényeként ismerik. ${ }^{6}$ Átalakulhat ugyan szilárdból folyékonynyá, gázzá vagy plazmává, helyzeti energiából mozgási energiává, de az univerzum teljes energiája/anyaga állandó marad. A termodinamika e főtétele és a szimmetria közötti kapcsolatot az ún. Noether-tétel mondja ki. Eszerint, ahol a természetben valamilyen szimmetria érvényesül, ott ahhoz megmaradási törvény tartozik. Vagyis a német matematikusnő, Emmy Noether tétele valójában a szimmetria és a termodinamika törvényeit kapcsolja össze. Ugyanakkor a megmaradás törvénye ennél még többet jelent, és maga után vonja a „megtakarítás” koncepcióját is. Ez arra utal, hogy amikor a természet valamilyen problémával áll szemben ( $p l$ milyen legyen a hópelyhek alakja vagy a DNS-molekulája), akkor mindig a legegyszerübb, leggazdaságosabb megoldást választja. A hópehely akkor a legstabilabb, amikor az alakja szimmetrikus hatszög; a tartós DNS-molekula pedig szimmetrikus dupla hélix. Az elvet „Ockham ${ }^{7}$ borotvájaként”, más néven a takarékosság elveként is ismerjük. Eszerint, ha egy jelenségre több magyarázat is lehetséges, akkor általában az egyszerübb megoldás a helyes. Ez alkalmazható a környezetpolitikában is: az legyen a lehető legegyszerübb. Ez azt is jelenti, hogy a környezetpolitika, amelyik túl komplex és bonyolult, az valószínűleg hibás. ${ }^{8}$

Az ekvivalencia elve Albert Einstein nevéhez köthető, aki 1907-ben rámutatott, hogy két, látszólag különböző erő - gravitáció és gyorsulás - valójában egy és ugyanaz. Ez rávilágított, hogy a gyorsulás és a gravitáció ugyanannak az erőnek a két megnyilvánulása (ekvivalencia elve). Ez vezetett az általános relativitáselmélet megalkotásához. Ehhez hasonlóan a tömeg és energia is ugyanaz. Az energia egyenlő a tömeg szorozva fénysebesség négyzetével $\left(E=m c^{2}\right.$, tömeg-energia ek-

5 Így azt is - jegyezhetjük meg -, hogy nemcsak antirészecskék, hanem antiatomok, sőt egyenesen antibolygók és antiuniverzumok is léteznek.

6 A (figyelmen kívül hagyott) termodinamikai korlátok jogi jelentőségére már Deák Dániel is utalt e folyóirat hasábjain. DEÁk Dániel: Környezeti adóharmonizáció és verseny-konform szabályozás az Európai Unió Bírósága gyakorlatának fényében. Pro Futuro, 2017/1, 95.

7 William Ockham 14. századi angol skolasztikus filozófus, ferences rendi szerzetes.

8 Jellemző, hogy a környezetjogi tankönyvek bemutatják, mennyire bonyolult szabályozásról van szó. A sokszínüséget ugyanakkor gyakran erényként tüntetik fel, amit a környezeti rendszer és az ártalmakkal járó tevékenységek sokféleségére vezetnek vissza. Mindemellett - ha a teljes alkalmatlanságot nem is - elismerik a szabályozás gyengeségeit és hiányosságait. Így FoDoR László: Környezetjog. Debreceni Egyetemi Kiadó, Debrecen, 2014, 9-69. Lásd még FODOR László: Milyen környezetjogunk legyen? Természet Világa - Természettudományi Közlöny, 2003/10, 457-459. 
vivalencia). Einstein a tömeg-energia ekvivalenciára egyszerüen a tér és idő szimmetriájából következtetett. Ha mindezt továbbgondoljuk, akkor arra juthatunk, hogy az ember nem felsőbbrendü a természethez képest, inkább csak részese egy hatalmas környezeti-társadalmi rendszernek. A környezetpolitikát pedig erre tekintettel úgy kell kialakítani, hogy annak címzettje a környezeti-társadalmi rendszer legyen.

A harmadik megnyilvánulása a szimmetriának az egység elve. Eszerint a természetben látszólag ellentétes erők vannak, ugyanakkor ezek mégis hasonló tulajdonságokkal rendelkeznek. Hasonlít az elv a rendszerelméletre, amely a rendszer egyes elemeinek elrendezésére, illetve az elemek közötti kapcsolatokra fókuszál. A rendszerelmélet szerint maga az egész több a független részelemektöl, a rendszer tulajdonságai nem következnek az alkotórészek jellegzetességeiböl. Az egység elve a Newton-féle gravitációs törvénytöl kezdve Einstein speciális relativitáselméletéig számos természettudományos eredményben megjelenik. Ez a jog- és politikaalkotók számára azt jelenti, hogy az embert nem tekinthetik és kezelhetik elkülönülten a természeti környezettöl. A környezeti-társadalmi rendszer egy komplex, heterogén és nem lineáris dinamikus rendszer, amiben az ember és természet lényegében ennek alkotórészei.

\section{Egy új környezetpolitika}

Végezetül Laitos részletesen kifejti, hogy milyen is az a környezetpolitika, amely összhangban van a szimmetria univerzális elvével és az ebből következő három követelménnyel. Ez az ideálisnak tartott környezetpolitika egy olyan jogot (right) biztosítana, amely nem az embereket és nem is a környezetet, hanem a környezeti-társadalmi rendszert együttesen illetné. Ez egy ún. „pozitív” jog lenne, egy olyan, környezeti feltételekhez való jog, amely lehetővé teszi a planetáris korlátok tiszteletben tartását, ezzel biztosítva az emberi túlélést a Földön. Általánosságban a „pozitív” jog (szemben a negatív jogokkal) úgy biztosít jogot a jogosult részére, hogy mások számára előírja, hogy közremüködjenek a jogosult jogának érvényre juttatásában. A jog célja ebben az esetben a földi ökoszisztéma megóvása és helyreállitása annak érdekében, hogy legyen egy az emberi társadalom számára alkalmas és biztonságos müködési tér (global safe operating space). Ez a jog egyben másoktól (különösen az emberektől) azt várja, hogy az emberi társadalom fejlődése és túlélése érdekében tegyenek a földi ökoszisztéma-rendszerek helyreállitása és fenntartása érdekében. E jog tehát nem egy negatív jog, amely az ökoszisztémát érintő bizonyos destruktív emberi magatartások ellen van, hanem egy olyan jog, amely egy majdani ökoszisztémáért, illetve ennek megvalósításáért végzett pozitív emberi közremüködésért van.

E jognak két lehetséges forrása lehet. A jog létjogosultsága egyfelöl származhat a jogosult természetéből (status-based). Mivel az embereket azért illetik bizonyos jogok, mert emberi lények, ezért - tekintve, hogy az ember a környezetének része -, a környezetet is ugyanúgy megilletik jogok, mint az embert (tehát létezésénél fogva). E pozitív jog forrása másfelöl alapulhat egyfajta eszközjellegü megközelítésen (instrumentalist). E tekintetben „a cél szentesíti az eszközt”, tehát a kívánt célból következtetünk visszafelé arra, hogy milyen jogok szükségesek a cél elérésé- 
hez. Ebben az esetben tehát a cél biztosítja a jog létjogosultságát. A továbbiakban Laitos - figyelemmel a Hohfeld-rendszerre ${ }^{9}$ - a javasolt jog kapcsán kiemeli, hogy a jogosult számára az lehetővé teszi annak változtatását (power, a magyar szakirodalomban: hatalmasság). Ez különösen fontos követelmény, tekintettel arra, hogy a környezeti-társadalmi rendszer komplex, adaptív és dinamikus. E sajátosság miatt fontos tehát, hogy a jogosultnak lehetősége legyen változtatni e jogra alapozott szabályozás, környezetpolitika tartalmán (rugalmasság).

Összhangban a szimmetria elvével (amely tökéletesen megnyilvánul a szerző által idézett Hohfeld-féle rendszerben is), a pozitív joggal (right) szemben érthető módon állna egy ugyancsak pozitív kötelezettség (duty) is. A pozitív jelző a kötelezettség szó előtt arra utal, hogy az több egyszerüen a jogsértéstől való tartózkodásnál. E kötelezettség alapján ugyanis olyan magatartást kellene tanúsítani, amely hozzájárul az ökoszisztéma fenntartásához (tehát nemcsak arról van szó, hogy előírják, hogy mit nem lehet tenni [például ne szennyezz, ne haladj át stb.], hanem azt várják el, hogy tegyünk is a jog biztosítása érdekében. Így például ültess fákat, hasznosíts újra stb.). Az ilyen jellegü kötelezettség ugyanis inkább összhangban van azokkal a modern kutatásokkal, amelyek szerint az embereket jobban ösztönzi, ha azt mondják nekik, mit tegyenek, ahelyett, hogy mit ne tegyenek. A kötelezettség alanya ugyanakkor - tekintve, hogy az antropocén korban az emberi tevékenység hatására változott meg minden drámai módon - csak az emberi társadalom lenne, nem a teljes környezeti-társadalmi rendszer. Az embereknek tehát tennie kellene azért, hogy fenntartsák a számukra élhető ökológiai rendszert. Ez a pozitív kötelezettség Laitos véleménye szerint pozitív externáliák és közjó ${ }^{10}$ létrehozásában (pl. egy fa ültetése) kellene, hogy testet öltsön. A kötelezettség teljesítéséhez azonban arra is szükség van, hogy az embereket tájékoztassák az ökoszisztéma és az emberi társadalom helyzetéröl, hogy megfelelő és valós idejü információval rendelkezzenek tevékenységük környezetre gyakorolt hatásairól. Ami a társadalom motiváltságát/ demotiváltságát illeti, a szerző emlékeztet minket arra, hogy az emberek nem feltétlenül racionális lények, így magatartásukat a racionalitáson, önzésen kívül például altruizmus, társadalmi nyomás, együttmüködés egyaránt befolyásolja. Ugyanakkor elismeri, hogy a szakirodalomban sokan szkeptikusak a társadalom tagjainak önzetlensége kapcsán, azok többnyire kételkednek abban, hogy ösztönzés vagy valamilyen egyéb jogérvényesítő eszköz nélkül az emberek többsége bármit is tenne a ,jó ügy" érdekében. Pedig e kötelezettség alanya nemcsak maga az emberi társadalom, hanem annak minden tagja külön-külön is lenne, már csak amiatt is, mert ahogy Laitos a könyv egy másik részében kiemeli: a környezeti ártalmak egyre nagyobb hányada pontosan az individuális környezetterhelések összeadódásából származik. Csakhogy a jogi szabályozás számára ez a legnehezebben kezelhető szint (technikai okokból ugyanis sokkal hatékonyabb egy-egy nagyobb környezethasználót kötelezni/ösztönözni valamire, mint az egyéneket).

9 A Hohfeld-rendszer vázlatához lásd BLUTMAN László: Az analitikus jogdogmatika keservei: jogosultság, szabadosság, hatalmasság. Jogelméleti Szemle, 2012/4, 15.

10 A közjó (public good) azokra a javakra vonatkozik, amelyek fogyasztásában nincs rivalizálás, és amelyekből senki nem zárható ki. 


\section{A racionális természetjogtól a klasszikus természetjogig - a könyvismertető gondolatai}

A könyv olvasása, ismertetése közben számos gondolat fogalmazódott meg bennem. Először is nagyon hasznosnak tartom Laitos írását mindenekelött amiatt, mert kimondja, amit már többen is pedzegetnek a hazai szakirodalomban (például Kerekes Sándor, Takáts-Sánta András, illetve jómagam) ${ }^{11}$ is: a környezetvédelmi szabályozás megbukott, vagy ez legalábbis hamarosan bekövetkezik. Ennek megítélése attól függ, hogy hogyan értékeljük azokat a könyvben is ismertetett természettudományos bizonyítékokat, amelyek a környezeti rendszernek az ember számára biztonságos létfeltételeket teremtő korlátainak az átlépésére utalnak. Vagyis mikor lesz visszafordíthatatlan a helyzet. A magam részéröl úgy vélem, hogy nyugodtan kimondhatjuk: a jelenlegi jogi szabályozás (minden szinten) müködésképtelen, mert nem biztosítja a környezeti korlátok tiszteletben tartásának a feltételeit. ${ }^{12}$ Vagy a könyv fogalomhasználatával élve: nem biztosítja az ember számára a biztonságos müködési teret, a jelenlegi emberi társadalom fennmaradásának alapfeltételét.

Természetesen, mint ahogy a földi ökoszisztéma is állandó, dinamikus változásban van, úgy az emberi társadalom is folyton változik, és miért ne halhatna ki az emberi faj - tehetnénk fel a kérdést minden elfogultság nélkül -, miként az elöfordul más fajokkal is a Földön. Ahogy a könyvben is olvasható, a szimmetria elve alapján összességében semmi sem változna, a Föld ökoszisztémája a maga egészében változatlan lenne, csak másfajta összetevők alakítanák ki az egyensúlyi helyzetet.

Persze hiába annak tudata, hogy egy nagyobb egész apró részei vagyunk, és a termodinamika első tétele alapján legfeljebb majd valamilyen más formában leszünk részei a nagy egésznek, a legtöbben mégsem tudunk ezzel azonosulni, az eltűnésünket „halálként” élnénk meg. Mindaddig, amíg az örökkévalósággal kapcsolatos tudásunkat nem tudjuk egyéni, illetve kollektív szinten megvalósítani, igenis van annak jelentősége, hogy hogyan maradhatnánk a lehető leghosszabb távon „életben”. Az időt pedig, amit egy esetleges önkorlátozással, visszalépéssel nyernénk, nem az eddigi hibák újbóli megismétlésére, hanem például annak a széles körü tudatosítására és gyakorlati megélésére kellene fordítani, hogy örök létezők vagyunk. ${ }^{13}$ A hosszú távú társadalmi fenntarthatóság biztosítása érdekében ezért az embernek a környezethez való viszonyulásán változtatni kellene, például abban, hogy tiszteletben tartja a környezeti korlátokat (illetve ha már megsértette azokat, akkor viszszalép a korlátok mögé). Pontosan ezért egyetértek Jan Laitosszal abban, hogy egy

11 KEREKES Sándor: A szenvedélyek féken tartása, avagy a fenntartható kapitalizmus? Köz-Gazdaság, 2016/4, 65-76; TAKÁCs-SÁNTA András-BódI Balázs: Tikopia társadalma, amely elkerülte a közlegelök tragédiáját. Socio, 2016/3, 91-104; BÁnYAl Orsolya: A jövő reménységei - a valóban fenntartható települések. Miskolci Jogi Szemle, 2017/2, 91-104.

12 Ezt a kérdést részletesen vizsgáltam; BánYAl Orsolya: Energiajog az ökológiai fenntarthatóság szolgálatában. DELA, Debrecen, 2014, 12-55.

13 Ezt a kijelentést a már ismertetett szimmetria elvére alapozom, de valójában hozzátehetjük, hogy erröl beszél az összes szentírás is a Földön: örök lelkek vagyunk. Lásd például Bhagavad-Gíta, 2.12. A Bibliában a halhatatlanság Isten kegyelmének a megnyilvánulása. Ld. TeológiaBlog, 2014. 11. 10.; https://www. teologiablog.hu/a-lelek-halhatatlansaga-6/ (2018. 03. 28.). 
úffajta környezetpolitikára lenne szükség, amely az elöbbi célt (a környezeti korlátok tiszteletével biztosítsunk az emberi társadalom számára megfelelő életteret) már szem előtt tartaná. Jelenleg ugyanis ezt a szükséges, de szigorú szemléletet a jogi szabályozás nem tudja magáénak. ${ }^{14}$

Az új környezetpolitikától Laitos azt várja, hogy az érvényesíti azokat az univerzális természeti törvényeket, amelyeket a természettudományok is elismernek: úgymint szimmetria, ekvivalencia, megmaradás, egység. Ezzel kapcsolatban úgy vélem, hogy az említett természeti törvények valójában nem törvények, hanem inkább jellemzők. Ezek a jellemzők akkor érvényesülhetnek és nyilvánulhatnak meg az emberi társadalomban, ha érvényesítjük a „korlátok tiszteletben tartásának követelményét". Arra, hogy ezalatt mit is értek, a későbbiek során még kitérek. De előtte engedtessék meg, hogy néhány ponton kiegészítsem Laitos gondolatmenetét.

Feltehetően az olvasónak is feltủnt, hogy amikor Laitos megfogalmazta javaslatát a planetáris korlátok tiszteletben tartásával kapcsolatos pozitív jogra és kötelezettségre, egy aszimmetriát is létrehozott. A jog kötelezettségpárja ugyanis csak az emberekre vonatkozna, a természeti környezetre, illetve annak elemeire nem.

Az egyik pluszelem, amit szeretnék beilleszteni, az egy erre irányuló javaslat. Vélelmet kellene felállítani, miszerint a természeti ökoszisztéma és annak elemei a kötelességüket maximálisan betartják. Aquinói Szent Tamás szerint is az „ésszel nem rendelkező teremtmények ösztönösen, szükségszerüen” követik az örök természeti törvényeket, és passzív módon vannak annak alávetve. ${ }^{15}$ Vagyis ök is kötelezettek, csakhogy ők ösztönösen betartják az univerzális törvényeket. Most eszünkbe juthatna, hogy de hát mi van azokban a helyzetekben (pl. természeti katasztrófa, állati kártételek stb.), amikor a természet okoz az embernek kárt? Erre az a válaszom, hogy a természet, a természeti elemek „magatartását” nem lehet emberi nézőpontból megítélni. Ez a megközelítés a középkori állatperekre volt jellemző, ahol a „törvénysértő” kártevőket (háziállatokat, sáskákat stb.) büntették ilyen vagy olyan módon, ember alkotta törvények alapján. ${ }^{16} \mathrm{~A}$ természeti környezet és elemei „magatartását” tehát az univerzális törvények alapján, és nem emberi törvények szerint kell megítélni.

Ez a megközelítés (univerzális rend és ahhoz való igazodást segítö törvények léte) például a klasszikus hindu jogi kultúrában teljesen természetes. „A Védák ${ }^{17}$ világképében ugyanis a kozmikus világrendnek van mindent meghatározó jelentösége, amely meghatározza a teremtett világ rendjét és müködését. E kozmikus világrend a rta (igazság, rend), mely [...] irányítja mind a makrokozmosz, mind a mikrokozmosz müködését, az anyagi világ, az istenek és az emberek viselkedését egyaránt meghatározva. Ebböl következően a világ egyes szereplöi között kölcsönhatás áll fenn, nem lehet egyetlen létezőt sem kiragadni az összefüggések e rendszeréböl. [...] A kozmikus világrend azonban csak abban az esetben áll, illetve tartható fenn, ha a

14 Lásd BÁnYAl (2014): i. m., 54.

15 Frivaldszky János: Természetjog. Szent István Társulat, Budapest, 2001, 19.

16 Dinzelbacher, Peter: Animal Trials: A Multidisciplinary Approach. Journal of Multidisciplinary History, 2002/3, 405-421.

17 A Védák a hinduizmus szentírásai. Nyelvük a szanszkrit, a világ egyik legősibb (ha nem a legősibb) nyelve. A véda szó azt jelenti, hogy „tudás”. Terebess Ázsia Lexikon. https://terebess.hu/keletkultinfo/lexikon/veda. html (2018. 03. 28.). 
világrend valamennyi résztvevője teljesíti a rá kirótt funkciókat." ${ }^{18}$ Ehhez szükséges a dharma követése. „A dharma a dhr gyökböl származik, mely fenntartást, megörzést jelent, utalva a dharma világrendet megörzö funkciójára. Amennyiben valaki a dharma alapján cselekszik, akkor ez biztositja funkciójának teljesitését. Fontos hangsúlyozni, hogy a dharma nem feltétlenül azt foglalja magában, ami »jó«, míg az adharma sem azt, ami »rossz". A dharma mindkettöt magában foglalja, mivel az élölények funkciójához [természetéhez - Bányai Orsolya megjegyzése] igazodik. Egy példával illusztrálva: az oroszlán dharmája, hogy öljön tápláléka biztositása céljából, de az értelmetlen, öncélú öldöklés már adharma." "19 A dharma tehát segíti a kozmikus világrendhez történő igazodást.

De nemcsak a védikus kultúrában, hanem Platón, Arisztotelész és Aquinói Szent Tamás gondolatrendszerében is ezzel (örök törvény - emberi törvény megkülönböztetése) találkozhatunk. Ezzel elérkeztünk oda, ahol felmerül a kérdés: a modern természettudományok által elfogadott univerzális törvények, illetve a Védákban is említett kozmikus világrend, a klasszikus természetjogi gondolkodók (mint Platón, Arisztotelész és Aquinói Szent Tamás) által felvázolt világkép lényegében nem egy és ugyanaz? Nem arról van-e szó, hogy miután a „felvilágosodás korában” szabad akaratunkból elszakadtunk a klasszikus természetjogi felfogástól, vagyis attól, hogy a társadalmi normákat, az emberi magatartásunkat egy örök rendhez kell igazítani, most szembesülve tetteink következményeivel (azzal, hogy az ökológiai korlátok, örök törvények megsértése miatt az emberi társadalom számára megszünni látszik a fennmaradásához szükséges biztonságos müködési tér), sejteni kezdjük, hogy valójában tévedtünk? Nem arról van-e szó, hogy nem merjük kimondani: a modern természettudományok eredményei ugyanazok, mint például a klasszikus természetjog és a Védákban is ismertetett világrend? Véleményem szerint erről van szó, a tények (akár az univerzális törvények létéröl, akár a természeti ökoszisztéma mai állapotáról) magukért beszélnek. Ahhoz, hogy hosszú távon fenntartható legyen a társadalmunk, újból vissza kellene térni a rendhez, követni az „örök” törvényeket.

Érdekes módon Jan Laitos nem utal gondolatmenete és a klasszikus természetjogi felfogás közötti hasonlatosságra. Pedig jogászként bizonyára ismeri a hagyományos természetjogi gondolkodást. Úgy látom azonban, hogy ezt a párhuzamot nem lehet említés nélkül hagyni, hiszen a klasszikus természetjogi felfogás és azok az egyetemes törvények, amelyekröl Laitos ír, majdnem ugyanazok. Majdnem. Egy különbség van, amelyik egyben okát is adhatja, hogy Laitos miért nem utal a klaszszikusokra. A klasszikus természetjog képviselöi ugyanis a természeti törvényeket nem fosztották meg transzcendentális jellegüktöl (vagyis elismerték, hogy azok valójában Isten törvényei). ${ }^{20}$ Laitos pedig azzal, hogy szó nélkül hagyta, megfosztotta e törvényeket e természetüktöl. Vajon van-e jelentősége ennek a különbségnek? Álláspontom szerint van, és úgy látom, hogy Laitos gondolatmenetét ezen a ponton is fontos kiegészíteni.

18 FrivaldsZKY: i. m., 19.

19 JANY János: A hindu jog ontológiai alapjai és forrásai. Iustum Aequum Salutare, 2007/1, 91-108.

20 A modern természetjog (pl. Grotius, Hobbes) viszont már elszakadt Istentől, és az emberhez kötött racionális természetjoggá vált. FRIVALDSZKY: i. m., 222. 
Azt a kettősséget (társadalom és természet dualitását), amiről Laitos problémaként ír, nem lehet ugyanis csupán a gondolkodás megváltoztatásával megoldani. Hiába tudja valaki elméleti szinten, hogy ő egy apró része a természeti környezetnek, amíg ezt nem képes átérezni (érezni, tapasztalni), addig az elméleti tudás ellenére önpusztítást fog végezni, egységet tagadó, destruktív, a korlátokkal mit sem törődő magatartásával. ${ }^{21}$ És miért van szükség az egységélmény átéléséhez a transzcendencia elismerésére? Azért, mert enélkül a tökéletes egységet nem lehet megtapasztalni, így a problémát csak részben oldanánk meg. A természeti-társadalmi környezettel való egység (az ökológiai én megtapasztalása) még nem a teljes kép. Ha érezzük is azt, hogy egyek vagyunk a természettel, a Földdel (Földanyával), szervesen kapcsolódunk hozzá, még mindig ott a minket körülvevő sötét és hideg univerzum és az egyedüllét, elszigetelődés érzése. ${ }^{22}$ Vagyis egy a Földnél is hatalmasabb, végtelen egész részei vagyunk, amely az én értelmezésem szerint nem más, mint maga Isten. Isten létét persze nem mindenki fogadja el, s e könyvismertetőnek sem lehet feladata az Olvasó meggyőzése erről. Mégis úgy vélem, legalább arra a szintre bárki könnyen eljuthat, hogy ne zárja ki a létezését. ${ }^{23}$

Ahogy mondani szokás, Isten létét lehetetlen bizonyítani természettudományos módszerekkel. A jogtudományban ugyanakkor ismerjük a bizonyításnak más módszereit is, például a tanúvallomást. Különböző korokban, szerte a Földön rengetegen tanúskodtak már Isten létezéséről (például Jézus Krisztus, Mózes, Mohamed, Assisi Szent Ferenc, Buddha, Srí Caitanya, Pio atya és még sorolhatnám). Napjaink világhírü magyar tudósa, Freund Tamás agykutató nagy feltünést keltett kijelentését is idézhetjük, mely szerint „az emberi agy a Teremtő müve”. ${ }^{24}$ Mindannyian köztiszteletben álló, elismert és a közjót szolgáló tekintélyek. Vajon lehet-e teljes világképről beszélni akkor, ha vallomásaikat kihagyjuk a bizonyítékok mérlegelése során? Feltehető emellett egy másik kérdés is: van-e annak így értelme?

Egyesek azt mondják, az igazi „egzakt” tudományok a szubjektum teljes kizárásával törekednek az objektív megismerésre. ${ }^{25}$ De vajon nem éppen a szubjekivitás, illetve ezzel együtt az érzelmek kizárása vezetett-e az olyan egzisztenciális problé-

21 Molnos Zselyke: Ökopszichológia-alapkönyv. HR-Line Kft., Budapest, 2016.

22 Hankiss Elemér például számos könyvében ír erröl az alapvető élményröl, amely a filozófusokat a legkülönbözőbb korokban a kozmosz „humanizálására” késztette, s természetesen a vallások kialakulását is áthatotta. Lásd különösen HANKIss Elemér: A befejezetlen ember - Gondolatok a világról, az emberröl, a szabadságról. Helikon, Budapest, 2014.

23 A környezetvédelmi szabályozás (a környezethez való jog) elvi-etikai alapjaihoz az ember Istennel, az emberekkel és a természettel való kapcsolata is hozzátartozik. BÁNDı Gyula: Környezetjog. Szent István Társulat, Budapest, 2014, 92-94.

24 Freund arra is rámutat, hogy pl. a gondolkodó, szabad akarattal rendelkező ember keletkezésének az értelme, a lelkünk eredete, küldetése és sorsa olyan kérdések, amelyekre a természettudomány sohasem fog tudni választ adni. Lásd Az agy a teremtő müve. Freund Tamás agykutatóval beszélget Mezei Károly. Kairosz, Budapest, 2005.

25 Ami a jogtudományt illeti, ez a gondolatmenet még elvezet ahhoz a problémához is, hogy a jogtudomány nem egzakt tudomány, sőt egyesek szerint még csak nem is tudomány. Lásd a ResearchGate blogbejegyzéseit az Is law a science? kérdés nyomán, amely négy éve generál élő diskurzust. https://www.researchgate.net/ post/ls_law_a_science (2018. 03. 28.); PoKol Béla: A jogtudomány társadalomtudományosodása. MTA Law Working Papers, 2015/13; A jogtudomány tudományosságáról egy klasszikus, HoRVÁtH Barna: Tudomány és jogtudomány. Erdélyi Tudományos Füzetek, 1944/3-4, 349-385; DEADWYLER, William: Tudomány és vallás, 
mákhoz, mint az embereknek egymástól és a világtól való elidegenedése, az emberi élet elgépiesedése vagy a természet megerőszakolása ${ }^{26} \mathrm{E}$ kérdésre nehezen adható más válasz, mint igen. Pont a kapcsolat megszakadása okozta mindezt, illetve az a tévhit, hogy mi különbek vagyunk a természetnél, $s$ uralhatjuk azt. ${ }^{27}$

Még egy kérdésre térek ki a bemutatott müvel kapcsolatban. Habár sok tekintetben egyetértek az abban leírtakkal (az említett univerzális törvények transzcendens, isteni jellegének elismerésével kapcsolatos kiegészítésem fenntartásával), mégis szükségesnek látom megemlíteni, hogy az univerzális törvények, amelyeket érvényesíteni kell a társadalmi fenntarthatóság érdekében, még önmagában kevésnek bizonyulnak ahhoz, hogy az emberek hétköznapi életében eligazodást nyújtsanak, tehát mindenképpen aprópénzre kellene váltani őket. Ez lényegében a hatályos pozitív jog megreformálását igényelné. Hogy az így létrejövő jogi szabályozás mennyire lehet rugalmas és egyszerü, ahogy azt Laitos számon kéri, azzal kapcsolatban (a jelenlegi szabályozás hihetetlen összetettségének ismeretében) kétségeim vannak. Mindenesetre az biztos, hogy a hatályos pozitív, ember alkotta jog, jelenleg nincs összhangban azzal az örök törvénnyel sem, hogy „tartsuk tiszteletben a korlátokat”. ${ }^{28}$ E törvény létét igazolja, hogy megindultak azok a folyamatok az ökoszisztémában, amelyek az emberi társadalom fennmaradását veszélyeztetik (ha ugyanis nem lenne törvénysértés, nem lenne az áthágásából származó negatív következmény sem). Van tehát egy nálunk nagyobb és hatalmasabb erő (legyen az a földi ökoszisztéma vagy maga Isten), amit tisztelni érdemes, ha nem akarunk a vesztünkbe rohanni.

hit és tudás - az ellentétek feloldása: Tattva, 1998/1; WILKINS, Maurice: Tudomány és spiritualitás. Tattva, 1998/1.

26 Deadwyler: i. m.

27 A kérdéskör valláserkölcsi hátterének teljes kibontására itt nincs mód. E kérdésekkel foglalkozik például WHITE, Lynn Jr.: Ökológiai válságunk történeti gyökerei. In: Lányi András-Jávor Benedek: Környezet és etika (szöveggyüjtemény). L'Harmattan, Budapest, 2005, 167-177; Livingstone, David N.: Ökológiai válságunk történeti gyökerei. Újraértékelés. In: Lányi András-Jávor Benedek: Környezet és etika (szöveggyüjtemény). L'Harmattan, Budapest, 2005, 178-200.

28 Az univerzális törvényt ésszel, csak korlátozott mértékben tudjuk követni. Ahogy Szent Ágoston írta, teljes mértékben csak az isteni kegyelem által élhetünk aszerint. FrIVALDSzkY: i. m., 67. 